\title{
Low back pain and fever as the first symptoms of AIDS: case report
}

\author{
Carlos Umberto Pereira1', Alyne Andrade Lima², Stephanie Chagas Feitosa²
}

Department of Medicine, Federal University of Sergipe (UFS), Service of Neurosurgery, HUSE, Aracaju, SE, Brazil.

\begin{abstract}
Each year, the number of acquired immunodeficiency syndrome (AIDS) cases increases significantly. The first symptoms of HIV infection can be variable, which difficulties the diagnosis at this stage. We report the case of a male patient, 46 year-old, presenting lumbar pain and fever for five days, no more complaints. Neurological examination and computed tomography (CT) of the lumbar spine normal. Serology for HIV showed positive. It started antiretroviral therapy obtaining resolution of the previous condition. The majority of HIV-infected patients present acute retroviral syndrome (ARS) early in infection. This syndrome includes nonspecific symptoms as fever, fatigue, arthralgia, myalgia, headache and anorexia. In seropositive patients, pain is a common symptom, bur poorly treated. The pain main appear in all stages of the disease, more frequent in advanced ones. The main sites of pain are head, legs and lower back. The symptomatic treatment of pain should be initiated quickly, even though the etiology is not possible. The treatment of pain in HIV patients may be diverse and requires polytherapy in most of cases. It is necessary to keep a high level of suspicion in all patients who presents compatible symptoms and reports recent risk behaviors. The early diagnosis and treatment are the key to good quality of life for these patients.
\end{abstract}

\section{KEYWORDS}

Acquired immunodeficiency syndrome, diagnosis, low back pain.

\section{RESUMO}

Dor lombar e febre como primeiros sintomas de SIDA: relato de caso

O número de casos de SIDA no mundo aumenta a cada ano. Os primeiros sintomas da infecção pelo vírus HIV podem ser bastante variados, tornando o diagnóstico difícil nessa fase. É relatado o caso de um paciente do sexo masculino, 46 anos, apresentando dor lombar e febre por cinco dias, sem mais queixas. Exame neurológico e tomografia computadorizada (TC) de coluna lombar sem alterações. Sorologia para HIV com resultado reagente. Iniciada terapia antirretroviral com resolução do quadro anterior. A maioria dos pacientes infectados pelo HIV apresenta síndrome retroviral aguda (SRA) no início da infecção. Essa síndrome inclui sintomas inespecificos como febre, fadiga, artralgia, mialgia, cefaleia e anorexia. Em pacientes soropositivos, a dor é um sintoma comum, mas ainda pouco tratada. A dor pode aparecer em todos os estágios da doença, mais frequente em estágios avançados. Os principais sítios de dor são cabeça, pernas e região lombar. O tratamento sintomático da dor deve ser iniciado rapidamente, mesmo que o diagnóstico etiológico não seja possível. O tratamento da dor em

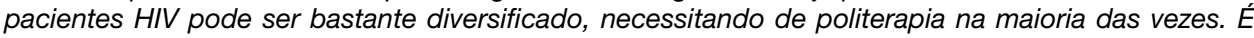
necessário manter um alto nível de suspeição em todos os pacientes com sintomas compatíveis e que relatam comportamento de risco recente. O diagnóstico e o tratamento precoces são fundamentais para uma boa qualidade de vida ao paciente.

\section{PALAVRAS-CHAVE}

Síndrome da imunodeficiência adquirida, diagnóstico, dor lombar.

1 Professor, Department of Medicine, Federal University of Sergipe (UFS), a neurosurgeon at the Emergency Hospital of Sergipe (HUSE), Aracaju, SE, Brazil.

2 Medical Student of UFS, Aracaju, SE, Brazil. 


\section{Introduction}

The number of people infected with HIV has increased in recent years. According to the World Health Organization (WHO) estimates that in 2010 there were 34 million people infected, while deaths number 1.8 million at the same year. ${ }^{1}$

The period between HIV infection and the manifestation of acquired immunodeficiency syndrome (AIDS) is not well defined and can last for months and even years. The initial symptoms presented differ greatly among patients and can range from fever, malaise, lethargy, anorexia, arthralgia, headache and generalized lymphadenopathy. ${ }^{2}$ In this paper, we describe a case for AIDS who had presented pain and fever as first symptoms.

\section{Case report}

Patient, male, 46-year-old, married, businessman, previously healthy. The patient presented to emergency department because of a five-day history of moderate low back pain and fever; he had not headache or vomiting. On examination, the patient was in a good general evaluation, presenting fever, his temperature was $38.5^{\circ} \mathrm{C}$. Neurological examination showed no focal deficits. Urinalysis for suspected urinary tract infection showed normal results. Computed tomography (CT) of lumbar spine showed normal. HIV serology performed by ELISA test present positive result that was confirmed by Western Blot test. The test to detect viral load showed 4,000 copies of HIV viruses per ml. The CD4 count was 330 per $\mathrm{mm}^{3}$. Then the treatment was initiated using specific antiretroviral therapy with zidovudine and efavirenz. The patient was discharged after three days obtaining resolution of the previous condition and continues ambulatory treatment.

\section{Discussion}

Most HIV-infected patients suffer from acute retroviral syndrome (ARS) at the beginning of the infection. This syndrome includes nonspecific symptoms flu-like as fever, fatigue, arthralgia, myalgia, headache and anorexia. ${ }^{3,4}$ Events occurring during ARS are important to determine the natural course of the disease. ${ }^{4}$ The diagnosis of ARS provides an opportunity to reduce opportunistic infections, introduce antiretroviral treatment at the right moment and prevent infection of the patient's partner. ${ }^{5}$
The diagnosis of ARS may be not so that easy. Sometimes the tests for viruses detection can be false negatives. Therefore, it is necessary that health professionals keep a high level of suspicion in all patients with compatible symptoms and who report recent risk behavior. ${ }^{6,7}$

The medical literature describes a wide range of clinical manifestations of primary infection, with fever and rash as the main signals. ${ }^{8}$ Neurological manifestations as brachial neuritis, peripheral neuropathy, facial palsy, lymphocytic meningitis and encephalopathy were also observed. ${ }^{9}$

In HIV seropositive patients, pain is a debilitating symptom very common, but it is still underestimated and poorly treated. ${ }^{10}$ Among them, women relate more pain than men. ${ }^{11}$ The pain may appear in all stages of the disease, more frequently in advanced ones, and its prevalence is as high as in oncologic patients. ${ }^{12}$ Progression to the final stage of the disease is influences by the severity of the symptoms of primary HIV infection, the duration of the disease and the presence of neurological symptoms. ${ }^{13}$

The different components of pain may vary according to the mode of transmission and disease treatment. It was seen more reports of pain in patients injecting drug users compared to other modes of transmission..$^{14}$ Besides the difference in pain intensity, pain sites also differ according to type, for example drug users present more pain as esophagitis and headache while non-users have more pain related to Kaposi's Sarcoma. The common sites of pain in both categories are abdominal and neuropathic. ${ }^{15}$

The pain can also present as a clinical manifestation of common mental disorders in primary infection with HIV, mainly headache, back pain and abdominal pain that may be atypical or show little response to treatment. ${ }^{16}$

The main sites of pain in HIV positive patients are head, legs and back. ${ }^{17}$ Low back pain in immunosuppressed patients can be explained as a symptom of ARS, as a manifestation of neuropathy or even as a possible symptom of Kaposi's Sarcoma and vertebrae lesion and spinal compression. ${ }^{18}$

In the case reported, the symptoms low back pain and fever are included in the symptoms of primary HIV infection, most likely manifestation of ARS. The suspicion for HIV infection was highly significant to the problem determination.

Symptomatic treatment of pain should be started even IF the diagnosis isn't completed, to preserve the patient. In case of etiological treatment is not possible, it should remain symptomatic treatment. ${ }^{19}$ The treatment of pain in HIV patients may be quite diverse. The answer to only one drug is not very effective and it can 
be necessary using multiple agents as amitriptyline, gabapentin, morphine and cannabis. ${ }^{20}$

The variety of early symptoms of AIDS is a point that should be carefully studied. The HIV viruses tests must be done in patients who present nonspecific symptoms as pain without apparent cause, especially in groups considered at risk. It is important to point AIDs as differential diagnosis in these cases.

Diagnosis and early appropriate treatment are the key to a good quality of life to patients. A multidisciplinary approach to pain management should be instituted, so it increases the chance of good recovering.

\section{Competing interests}

The authors declare that they have no competing interests.

\section{References}

1. World Health Organization (WHO). Data and statistics. Available at: $<$ http://www.who.int/hiv/data/en/>. Accessed on: Feb 11, 2013.

2. Cooper DA, Gold J, Maclean P, Donovan B, Finlayson R, Barnes TG, et al. Acute AIDS retrovirus infection. Definition of a clinical illness associated with seroconversion. Lancet. 1985;1(8428):537-40.

3. Guidelines for the use of antiretroviral agents in HIV-infected adults and adolescents. Department of Health and Human Services and Henry J. Kaiser Family Foundation. MMWR Recomm Rep. 1998;47(RR-5):43-82.

4. Zetola NM, Pilcher CD. Diagnosis and management of acute HIV infection. Infect Dis Clin North Am. 2007;21(1):19-48.

5. Sudarshi D, Pao D, Murphy G, Parry J, Dean G, Fisher M. Missed opportunities for diagnosing primary HIV infection. Sex Transm Infect. 2008;84(1):14-6.

6. Dubrow R, Sikkema KJ, Mayer KH, Bruce RD, Julian P, Rodriguez I, et al. Diagnosis of acute HIV infection in Connecticut. Conn Med. 2009;73(6):325-31.
7. Soogoor M, Daar ES. Primary HIV-1 infection: diagnosis, pathogenesis, and treatment. Curr Infect Dis Rep. 2005;7(2):147-53.

8. Hecht FM, Busch MP, Rawal B, Webb M, Rosenberg E, Swanson $M$, et al. Use of laboratory tests and clinical symptoms for identification of primary HIV infection. AIDS. 2002;16(8):1119-29.

9. Mahé A, Bruet A, Chabin E, Fendler JP. Acute rhabdomyolysis coincident with primary HIV-1 infection. Lancet. 1989;2(8677):1454-5.

10. Larue F, Fontaine A, Colleau SM. Underestimation and undertreatment of pain in HIV disease: multicentre study. BMJ. 1997;314(7073):23-8.

11. Norval DA. Symptoms and sites of pain experienced by AIDS patients. S Afr Med J. 2004;94(6):450-4.

12. Coughlan M. Pain and palliative care for people living with HIV/AIDS in Asia. J Pain Palliat Care Pharmacother. 2003;17(3-4):91-104.

13. Apoola A, Ahmad S, Radcliffe K. Primary HIV infection. Int J STD AIDS. 2002;13(2):71-8.

14. Del Borgo C, Izzi I, Chiarotti F, Del Forno A, Moscati AM, Cornacchione $\mathrm{E}$, et al. Multidimensional aspects of pain in HIV-infected individuals. AIDS Patient Care STDS. 2001;15(2):95-102.

15. Newshan GT, Wainapel SF. Pain characteristics and their management in persons with AIDS. J Assoc Nurses AIDS Care. 1993;4(2):53-9.

16. Thom R. Common mental disorders in people living with HIV/AIDS. South Afr J HIV Med. 2009;10(3):8-13.

17. Nair SN, Mary TR, Prarthana S, Harrison P. Prevalence of pain in patients with HIV/AIDS: a cross-sectional survey in a South Indian State. Indian J Palliat Care. 2009;15(1):67-70.

18. Di Bella S, Capone A, Olearo F, Johnson E, Chinello P, Baiocchini $A$, et al. Vertebral lesions from AIDS-Related Kaposi's sarcoma. Curr HIV Res. 2011;9(4):270-5.

19. Wesselmann U. Pain syndromes in AIDS. Anaesthesist. 1996;45(11):1004-14.

20. Smith HS. Treatment considerations in painful HIV-related neuropathy. Pain Physician. 2011;14(6):E505-24.

Endereço para correspondência

Carlos Umberto Pereira

Av. Augusto Maynard, 245/404

Bairro São Jose

49015-380 - Aracaju, SE, Brazil

E-mail: umberto@infonet.com.br 